\title{
New acquisitions in the physiopathology of multiple myeloma: Role of the bone microenvironment
}

\author{
Novos conhecimentos da fisiopatologia do mieloma múltiplo: o papel do microambiente medular
}

Nicola Giuliani

Vittorio Rizzoli

\begin{abstract}
Multiple myeloma (MM) is a plasma cell malignancy characterized by the accumulation of malignant plasma cells within the bone marrow (BM). MM cells interact with the microenvironment and induce pathological modifications that in turn support the growth and survival of MM cells. The BM microenvironment consists of various extracellular matrix proteins, and cell components as haematopoietic stem cells, progenitor and precursor cells, immune cells, erythrocytes, BM stromal cells (BMSCs), BM endothelial cells, as well as osteoclasts and osteoblasts that are able to secret several growth factors for MM cells. The direct interactions of MM cells with the microenvironment and the secreted cytokines activate signalling pathways mediating growth, survival, drug resistance and the migration of MM cells as well as osteoclastogenesis and angiogenesis. In this article we underline in particular the new evidences at the basis of the interaction between MM cell and bone cells and the potential role of osteoclast and osteoblast in MM pathophysiology. Rev. bras. hematol. hemoter. 2008;30(Supl. 2):3-5.
\end{abstract}

Key words: Multiple myeloma; physiopathology; bone microenvironment.

\section{Introduction}

Multiple myeloma (MM) is a plasma cell malignancy characterized by the accumulation of malignant plasma cells within the bone marrow (BM). MM cells interact with the microenvironment and induce pathological modifications that in turn support the growth and survival of MM cells. The BM microenvironment consists of various extracellular matrix proteins, including fibronectin, collagen, laminin and osteopontin; and cell components as haematopoietic stem cells, progenitor and precursor cells, immune cells, erythrocytes, BM stromal cells (BMSCs), BM endothelial cells (BMECs), as well as osteoclasts and osteoblasts.

$\mathrm{BM}$ microenvironment cells secrete several growth factors including interleukin 6(IL6), insulin-like growth factor 1 (IGF1), vascular endothelial growth factor (VEGF), B-cell activating factor (BAFF), fibroblast growth factor (FGF), stromal cell-derived factor 1 (SDF1), and tumour necrosis factor- (TNF), which are further upregulated by tumour cell adhesion to extracellular proteins and/or BMSCs.$^{1-2}$ The direct interactions of MM cells with accessory cells and secreted cytokines activate signalling pathways mediating growth, survival, drug resistance and the migration of multiple myeloma cells as well as osteoclastogenesis and angiogenesis. The major signalling pathways activated by the cytokines and cell adhesion are extracellular signalregulated kinase (ERK); Janus kinase 2 (JAK2)-signal transducer and activator of transcription 3 (STAT3); phosphatidylinositol 3-kinase (PI3K)-Akt; and/or nuclear factor B (NF B). Their downstream targets include: cytokines, such as IL6, IGF1, VEGF; anti-apoptotic proteins, such as BCL-XL, myeloid cell leukaemia sequence 1 (MCL1); and cellcycle modulators (cyclin D). Adhesion-mediated activation of NF B upregulates adhesion molecules such as intercellular adhesion molecule 1 (ICAM1) and vascular cell adhesion molecule 1 (VCAM1) on both multiple myeloma cells and BMSCs, thereby further increasing the binding of multiple myeloma cells to BMSCs. Secretion of angiogenic factors,

Hematology and BMT Center, University of Parma.

Correspondence: Nicola Giuliani

Chair of Hematology and BMT Center, Department of Internal Medicine and Biomedical Science, University of Parma

Via Gramsci 14

43100 - Parma, Italy

Phone: 00390521903299; Fax: 00390521903264

E-mail: Nicola.Giuliani@unipr.it 
such as VEGF, basic FGF (bFGF) and hepatocyte growth factor (HGF), from multiple myeloma cells and BMSCs stimulates neo-angiogenesis. ${ }^{1-2}$

\section{MM cells and bone microenvironment}

Among the complex interactions between MM cell and the microenvironment those involving osteoclast and osteoblast are the hallmark of MM. Bone destruction occurs in almost $70 \%$ of MM patients and it is mainly due to the activation of osteoclastic cells and bone resorption together with the inhibition of osteoblast formation induced by MM cells. On the other hand in the last years growing evidences have highlighted that both osteoclasts and osteoblasts may affect MM cells growth and survival being involved in the pathophysiology of MM.

Several evidences suggest that RANKL/OPG alteration is involved in the induction of osteoclastogenesis and osteoclast activity in MM. ${ }^{3-4}$ It has been demonstrated that MM cells induce RANKL expression in stromal/osteoblastic cells and they decrease OPG production by osteoblastic cells inducing an imbalance of RANKL/OPG ratio in favor of RANKL. The cell-to-cell contact is involved in the induction of RANKL in the microenvironment by MM cells through the integrin system VLA-4/VCAM-1 as demonstrated by blocking anti-VLA-4 antibody that completely blunted the induction of RANKL by MM. On the other hand, blocking anti IL-6, IL-1 or TNF $\alpha$ antibodies had no effect on RANKL induction. The role of the VLA-4/VCAM-1 interaction in the activation of osteoclastic cells by myeloma cells has been also reported in a murine model of MM-induced bone disease showing that the blocking of VLA-4 binding of myeloma cells to VCAM-1 on stromal cells decreases the release of bone by resorbing factors by stromal cells and suppresses the development of osteolytic bone lesions. ${ }^{5}$ The critical role of RANKL in MM-induced bone disease has been further confirmed in mouse models. ${ }^{3,6}$ In these models RANKL specific inhibitors OPG or RANK-Fc. completely blocked bone destruction with a significant reduction of the number of osteoclastic cells. Administration of both RANK-Fc and OPG also caused a marked reduction of tumor burden assessed histologically and serum paraprotein in the serum accompanied by restoration of OPG and RANKL expression within the human xenograft. ${ }^{3,6}$

The histomorphometric studies performed in MM patients have demonstrated that a reduction of the number of osteoblastic cells contributes together with the increase of osteoclast activity to the development of bone lesions. ${ }^{7}$ In physiological condition, the formation and differentiation of osteoblastic cells from mesenchymal/stromal cells require the activity and function of the transcription factor Runx $2 / \mathrm{Cbfa} 1$. The potential involvement of Runx2/Cbfa1 in MM induced osteoblast inhibition has been recently highlighted. ${ }^{8}$ Experimental data show that human MM cells are able to inhibit osteoblast differentiation in long term BM culture, reducing the number of both fibroblast colony-forming unit (CFU-F) and the colony-forming bone nodule units (CFU-OB) supported by the inhibitory effect observed on the expression of osteoblast differentiation markers as alkaline phosphatase, osteocalcin and collagen I in a short term co-culture system performed between myeloma cells and osteoprogenitor cells This effect seems to be mediated by blocking Runx $2 / \mathrm{Cbfa} 1$ activity in human osteoprogenitor cells. Indeed, it has been demonstrated that human MM cells inhibit Runx2/Cbfa1 activity in BM osteoprogenitor cells inhibiting the osteoblast differentiation process. The effect of MM cells on Runx2/ Cbfa1 activity is mainly mediated by the cell-to-cell contact between MM and osteoprogenitor cells with the involvement of the VLA-4/VCAM-1 interaction as demonstrated by the capacity of neutralizing anti-VLA-4 antibody to reduce the inhibitory effect on Runx2/Cbfa1 activity by MM cells. Clearly, other molecules involved in the myeloma cell adhesion could be implicated in the inhibition of osteoblastogenesis by human myeloma cells. Recent data indicate that the NCAMNCAM interaction between myeloma cells and stromal/ osteoblastic cells may decrease bone matrix production by osteoblastic cells and contribute to the occurrence of bone lesions in MM patients. ${ }^{9}$ Soluble factors may contribute to the inhibitory effect of MM cells on osteoblast differentiation and Runx2/Cbfa1 activity as interleukin-7 (IL-7). ${ }^{8}$

The Wnt signaling is also involved in the regulation of osteoblast formation either through its canonical pathway, mediated by $\beta$-catenin nuclear translocation, or at least in part through its non-canonical one. ${ }^{10}$ Canonical Wnt signaling pathway is activated by Wnt $1 / 3 \mathrm{a}$, produced in both autocrine and paracrine fashion, and it interacts with Lrp5-6/Fzd receptor complexes. ${ }^{10}$ Several molecules negatively regulate canonical Wnt signaling with different mechanisms. Dickkopfs (DKKs) including DKK-1, the secreted frizzled related proteins (sFRPs) as sFRP1-4 and Wnt inhibitory factor (Wif-1) are the main soluble Wnt inhibitors in murine osteoblasts able to block early osteoblast formation inducing death of immature cells but also to stimulate terminal differentiation indicating a dual effect of Wnt signaling in the osteoblastogenesis. ${ }^{10}$ The potential involvement of Wnt signaling in the suppression of osteoblast formation and function in MM has been recently hypothesized. ${ }^{11}$ It has been reported that $\mathrm{CD} 138^{+} \mathrm{MM}$ cells obtained at the diagnosis from MM patients overexpress DKK-1 as compared to MGUS and normal plasma cells and a tight relationship between DKK1 expression by MM cells and the occurrence of focal lytic bone lesions has been demonstrated in MM patients. ${ }^{11}$ On the other hand patients with advanced disease as well as human myeloma cell lines do not express DKK-1 suggesting that DKK-1 mediated bone destruction could occur in the early phase of disease. Moreover it has been reported that neutralizing anti-DKK-1 antibody blocks the inhibitory effect of BM plasma of MM patients on BMP-2 
induced alkaline phosphatase expression and osteoblast formation by murine mesenchymal cell line and inhibit MMinduced bone destruction in MM mouse models ${ }^{11-12}$ but failed to blunt the inhibitory effect on human BM osteoblast formation by MM cells. ${ }^{8}$

Other than the block of osteoblast formation several evidences indicate that MM cells may directly act on mature osteoblastic cells. It has been demonstrated that myeloma cells are able to inhibit osteoblast proliferation and up-regulate osteoblast apoptosis in co-culture. ${ }^{13}$ Moreover osteoblasts obtained from MM patients with extensive bone lesions seem to be highly prone to apoptosis as compared to those without bone lesions. ${ }^{13}$ Besides killing osteoblast human MM cells sensitize osteoblastic cells to cell death mediated by recombinant TRAIL and in turn osteoblastic cells protect MM cells from TRAIL-mediated apoptosis. ${ }^{13}$ In line with this evidence it has been demonstrated that osteoblastic cells may inhibit MM cells proliferation ${ }^{14}$ and that increasing bone formation in MM mouse model is associated to a reduction of MM burden. ${ }^{15}$

In conclusion several new evidences have clarified the biological mechanisms at the basis of MM and bone cells interaction identifying new potential therapeutic targets.

\section{Resumo}

O mieloma múltiplo (MM) é uma doença maligna das células plasmáticas caracterizada pelo acúmulo de células plasmáticas na medula óssea (MO). As células do MM interagem com o microambiente e induzem modificações patológicas que, por seu turno, propiciam o crescimento e a sobrevida das células do MM. O microambiente da MO consiste de várias proteinas da matriz extracelular e de componentes hematopoéticos: células-tronco, progenitoras e precursoras, células imunes, eritrocitárias, estromais, endoteliais. Possuem também osteoclastos e osteoblastos capazes de secreção de fatores de crescimento das células do MM. A direta interação das células mielomatosas com o microambiente e a secreção de citocinas ativam cascatas sinalizadoras que mediam o crescimento, sobrevida, resistência a drogas e a migração destas células assim como a osteoclastogênese e a angiogênese. Neste artigo explicitamos novas evidências e as bases da interação das células mielomatosas e as células medulares e o provável papel dos osteoclastos e dos osteoblastos na fisiopatologia do MM. Rev. bras. hematol. hemoter. 2008;30(Supl. 2):3-5.

Palavras-chave: Mieloma múltiplo; fisipatologia; microambiente medular.

\section{References}

1. Podar K, Richardson PG, Hideshima T, Chauhan D, Anderson KC. The malignant clone and the bone-marrow environment. Best Pract Res Clin Haematol. 2007;20(4):597-612.

2. Hideshima T, Mitsiades C, Tonon G, Richardson PG, Anderson KC. Understanding multiple myeloma pathogenesis in the bone marrow to identify new therapeutic targets. Nat Rev Cancer. 2007;7(8):585-98.
3. Pearse RN, Sordillo EM, Yaccoby S, Wong BR, Liau DF, Colman $\mathrm{N}$, et al. Multiple myeloma disrupts the TRANCE/ osteoprotegerin cytokine axis to trigger bone destruction and promote tumor progression. Proc Natl Acad Sci USA. 2001;98(20):11581-6.

4. Giuliani N, Bataille R, Mancini C, Lazzaretti M, Barillé S. Myeloma cells induce imbalance in the osteoprotegerin/osteoprotegerin ligand system in the human bone marrow environment. Blood 2001;98(13):3527-33.

5. Michigami T, Shimizu N, Williams PJ, Niewolna M, Dallas SL, Mundy GR, et al. Cell-cell contact between marrow stromal cells and myeloma cells via VCAM-1 and alpha(4)beta(1)-integrin enhances production of osteoclast-stimulating activity. Blood 2000;96(5):1953-60.

6. Croucher PI, Shipman CM, Lippitt J, Perry M, Asosingh K, Hijzen $\mathrm{A}$, et al. Osteoprotegerin inhibits the development of osteolytic bone disease in multiple myeloma. Blood 2001;98(13):3534-40.

7. Bataille R, Chappard D, Marcelli C, Dessauw P, Sany J, Baldet P, et al. Mechanisms of bone destruction in multiple myeloma: the importance of an unbalanced process in determining the severity of lytic bone disease. J Clin Oncol. 1989;7(12):1909-14.

8. Giuliani N, Colla S, Morandi F, Lazzaretti M, Sala R, Bonomini S, et al. Myeloma cells block RUNX2/CBFA1 activity in human bone marrow osteoblast progenitors and inhibit osteoblast formation and differentiation. Blood. 2005;106(7):2472-83.

9. Ely SA, Knowles DM. Expression of CD56/neural cell adhesion molecule correlates with the presence of lytic bone lesions in multiple myeloma and distinguishes myeloma from monoclonal gammopathy of undetermined significance and lymphomas with plasmacytoid differentiation. Am J Pathol. 2002;160(4):1293-9.

10. Westendorf JJ, Kahler RA, Schroeder TM. Wnt signaling in osteoblasts and bone diseases. Gene. 2004;341:19-39.

11. Tian E, Zhan F, Walker R, Rasmussen E, Ma Y, Barlogie B, et al. The role of the Wnt-signaling antagonist DKK1 in the development of osteolytic lesions in multiple myeloma. N Engl J Med. 2003;349(26):2483-94.

12. Yaccoby S, Ling W, Zhan F, Walker R, Barlogie B, Shaughnessy JD Jr. Antibody-based inhibition of DKK1 suppresses tumor-induced bone resorption and multiple myeloma growth in vivo. Blood. 2007;109(5):2106-11.

13. Silvestris F, Cafforio P, Tucci M, Grinello D, Dammacco F. Upregulation of osteoblast apoptosis by malignant plasma cells: a role in myeloma bone disease. Br J Haematol. 2003;122(1):39-52.

14. Yaccoby S, Wezeman MJ, Zangari M, Walker R, Cottler-Fox M, Gaddy D, et al. Inhibitory effects of osteoblasts and increased bone formation on myeloma in novel culture systems and a myelomatous mouse model. Haematologica. 2006;91(2):192-9.

15. Edwards CM, Edwards JR, Lwin ST, Esparza J, Oyajobi BO, McCluskey B, et al. Increasing Wnt signaling in the bone marrow microenvironment inhibits the development of myeloma bone disease and reduces tumor burden in bone in vivo. Blood. 2008;111(15):2833-42.

O tema apresentado constou do programa do Encontro AIBE. Avaliadores: Professores Ângelo Maiolino, Cármino Antonio de Souza e Marcio Nucci.

Publicado após concordância do editor.

Conflito de interesse: não declarado.

Recebido: 09/05/2008

Aceito: 20/05/2008 